\title{
Additional Archaeological Survey for the San Antonio 201 Wastewater Treatment Project
}

Cristi Assad

Follow this and additional works at: https://scholarworks.sfasu.edu/ita

Part of the American Material Culture Commons, Archaeological Anthropology Commons, Environmental Studies Commons, Other American Studies Commons, Other Arts and Humanities Commons, Other History of Art, Architecture, and Archaeology Commons, and the United States History Commons

Tell us how this article helped you.

This Article is brought to you for free and open access by the Center for Regional Heritage Research at SFA ScholarWorks. It has been accepted for inclusion in Index of Texas Archaeology: Open Access Gray Literature from the Lone Star State by an authorized editor of SFA ScholarWorks. For more information, please contact cdsscholarworks@sfasu.edu. 
Additional Archaeological Survey for the San Antonio 201 Wastewater Treatment Project

\section{Creative Commons License}

\section{(c) (1) (8)}

This work is licensed under a Creative Commons Attribution-NonCommercial 4.0 International License 


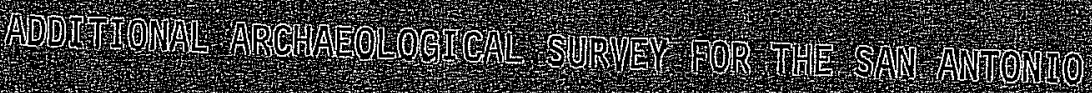

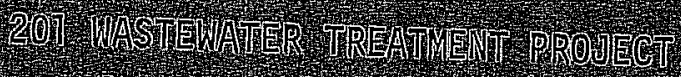

Gin

Centen

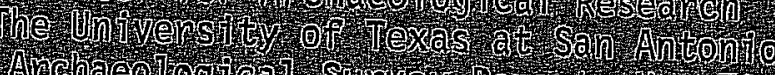

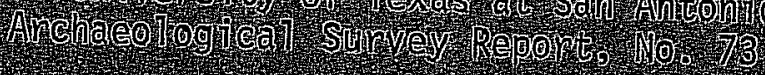

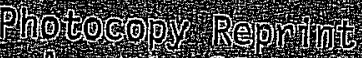

Augdist st 19.85 
- ADDITIONAL ARCHAEOLOGICAL SURVEY FOR THE SAN ANTONIO 201 WASTEWATER TREATMENT PROJECT

Cristi Assad

UTSA - Center for
Archaeological Research

Center for Archaeological Research

The University of Texas at San Antonio

Archaeological Survey Report, No. 73

1979 


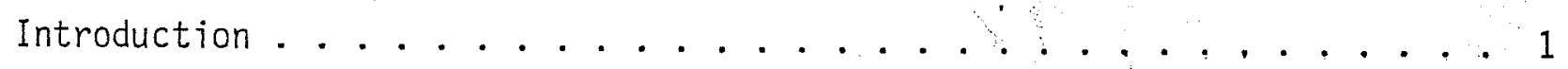
Leon Creek Planning Area . . . . . . . . . . . . . . . . . . . 3 Salado Creek Planning Area . . . . . . . . . . . . . . . . . 4 Conclusions. . . . . . . . . . . . . . . . . . . . . . . . 5 Recommendations. . . . . . . . . . . . . . . . . . . . . . . 5 References Cited . . . . . . . . . . . . . . . . . . . 5 $-$

\section{LIST OF FIGURES}

Figure

1. Map of Survey Areas. . . . . . . . . . . . . . . . . . . . . . . 2 


\section{INTROUUCTION}

During January 1979, personnel from the Center for Archaeological Research, The University of Texas at San Antonio, carried out archaeological surveys along five different drainages in two sewage treatment plant areas of northern Bexar. County. The current project is an addition to the work begun by Fox (1977) in Phase I to assess archaeological resources for preparation of an Environmental Impact Statement for the San Antonio 201 Nastewater Treatment Facilities Project.

The survey was conducted by Cristi Assad with the assistance of A. Joachim McGraw. This report has been prepared as a supplement to the Fox (1977) report and is modeled to conform with that work. All pertinent methodology, previous archaeological research, environmental and geological information and 1 ithic descriptions applying to this report are presented in Fox (ibid.) The general location of the areas surveyed is shown in Fig. 1 . 


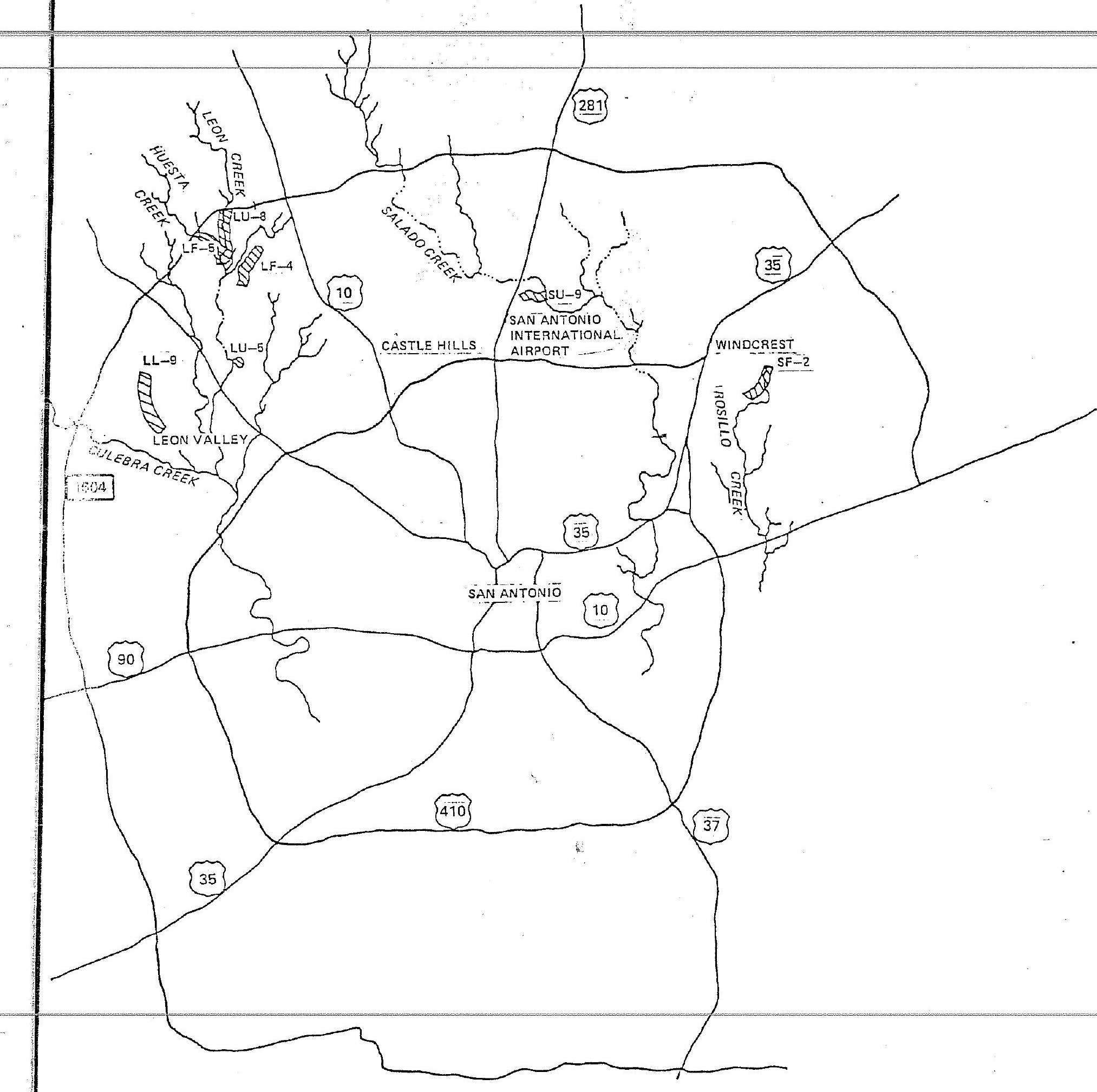

Figure 1. Map of Survey Areas. This is a simplified map of some of the drainages and highways of San Antonio. The areas numbered LL-9, LF-5, etc., are the extensions covered by the survey. A detailed map with the exact site location of 41 BX 473 has been provided to the Radian Corporation and the Texas Archeological Research Laboratory (Austin). 
LEON CREEK PLANNING AREA

Extension LL-9 runs along a seasonal drainage north of Culebra Creek and Culebra Road. It continues north in the drainage and ends west of the junction of Guilbeau and Tezel Roads. Much of this area has been altered by modern activities. The northern third of the area has been enveloped in suburban development and is greatly changed. The remaining survey area is less altered. The central section is made up of dense thickets of mesquite, hackberry, agarita, live oak and some prickly pear. There are some cleared, fallow agricultural fields at the southernmost end of the proposed sewage pipeline on the east side of the creek and some houses on the west side. The geology of the survey area is comosed mostly of fluviatile terrace deposits and Austin Chalk (Barnes 1974). io archaeological sites were found.

Extension LU-5 starts on the east side of Leon $\overrightarrow{C r e e k}$ and runs east $0.5 \mathrm{~km}$ to onnect at Rochelle Road just south of Whitby Road. The area is very smal1 and Ss completely covered by several houses. The vegetation on this steep bluff over Leon Creek is composed of grasses (1awns) and some scattered live oaks. according to one of the landowners, there is a buried well near the intersection of Whitby and Rochelle Roads. This well was once associated with the stagecoach ine, which the local residents believed to have run from San Antonio to the arthwest. Little physical evidence of the well or any other historic structures is visible. The geology of the survey area is Austin Chalk (Barnes 1974). No archaeological sites were found.

Extension LF-4 begins at a side drainage of Leon Creek $0.4 \mathrm{~km}$ south of Babcock Road and extends northeast along the shallow drainage to Hausman Road. The land on the west side of the drainage is relatively flat flood plain and has almost a 71 been plowed in the past. The east side of the drainage is much more varied. The northern and southern portions are composed of gently rolling grassy slopes. Most of the brushy vegetation has been cleared away. The central area is composed of a series of sma11, moderately steep, brushy hills or ridges. Vegetation on these ridges consists of thickets of cedar, persimmon and oak with prickly pear and yucca nearby. The geology of the area is Buda Limestone (Barnes 1974).

Site LF4-1 (41 BX 473) is a 1ithic scatter.. It consists of a thin deposit of chert flakes along a $150 \mathrm{~m}$ long by $50 \mathrm{~m}$ wide area which follows the ridge edge. A dirt road cuts through the site. Two very thick and crudely-made bifaces were found. The predominant materials at the site, however, are interior and secondary flakes. There is no native chert source in the immediate area. This site warrants no further action.

Extension LF-5 begins at Loop 1604 and parallels Hausman Road eastward along Huesta Creek, where it curves to the south, crosses Hausman Road and joins Extension LU-8 $0.8 \mathrm{~km}$ from its southern end. Most of the area is fluviatile terrace deposits, with only the extreme eastern end, where the majority of the surburban development is Tocated, in Edwards Limestone (Barnes 1974). This is 
the only one of the extensions surveyed that is located on the chert bearing Edwards Limestone formation. The vegetation is composed of areas of mesquite, cedar, persimmon, agarita and prickly pear, alternating with cleared and plowed fields of various grain plants. No archaeological sites were found.

Extension LU-8 runs roughly parallel to Babcock Road along Leon Creek. It begins $1.4 \mathrm{~km}$ south of Hausman Road and continues north to Loop 1604 . The northern half of the area is of Del Rio clay deposits, changing to low Quaternary terrace ceposits in the southern half (Barnes 1974). There is a small concentration of whards Limestone at the junction of Hausman and Babcock Roads. The vegetation inoughout the area ranges from varied patches of dense mesquite, cedar, agarita ant prickly pear to more open fields of grasses and some cleared fields. There is axtensive land development along Hausman and Babcock Roads. To the south, min of the east side is composed of pasture and plowed fields, while the west sis, much as the northern half, is composed of grassy fields with thickets of inghy plants dispersed throughout. No archaeolggical sites were found in this artension.

\section{SALADO CREEK PLANNING AREA}

Exension SF-2 starts at Castle Green Road and extends northeast, where it cosses Walzem Road, continuing north $1.0 \mathrm{~km}$ along Rosil10 Creek, The clay and marl terraces of the area slope gently to the creek (Barnes 1974). In tre northern section, there has been extensive land clearing and burning on the west side of the creek, while several houses are under construction along the east side of the creek edge to Walzem Road. The remainder of the survey area south of Walzem Road consists of plowed fields. There is a tremendous amount of chert cobbles (mostly small) throughout these fields. Geologically, there are no primary chert deposits in the immediate vicinity, and the source of this secondary chert deposit is unknown. Throughout this area, several flakes and a few cores were observed. The majority of this chert is in its natural, unmodified form, however. Upon investigation of an unplowed area, the same type of cobbles were seen, but there was absolutely no breakage. Our conclusions with respect to this unusual area are that it could have been a chert source used by the native populations, but at this time there is little evidence to support this theory. No archaeological sites were found,

Extension SU-9 starts at N. Loop Road, east of San Pedro Road, and zigzags to the east, ending at Salado Creek and Jones-Maltsberger Road. At one time this area was mostly residential. Several smal7 businesses still remain along JonesMaltsberger Road, but most of the houses and vegetation have been torn down from a point $100 \mathrm{~m}$ south of Clydeville Road towards the south in order to be added onto the San Antonio International Airport lands. A cut Timestone well] is located on land near Salado Creek several hundred meters away from the proposed sewer line. The landowners know nothing. of its orgin except that it and a rock wall were on the property prior to their purchase of the land during the 1920s. No archaeological sites were found. 
CONCLUSIONS

No significant prehistoric or historic archaeological sites were noted in the areas surveyed. One prehistoric site was recorded; but due to its damaged condition and the sparsity of its artifact inventory, the site is not believed to be of particular importance. The lack of archaeological sites in the survey area may be due to several factors: (1). modern development ray have destroyed existing sites; (2) sites may be covered by stream al7uvium; (3) some of the streams may have been too intermittent for other than sporadic use; and (4) there is a lack of natural resources which would draw inhabitants to the area. Without subsurface excavation, it is not possible to ascertain what archaeological remains may have been buried by modern development or by geological processes.

\section{RECOMMENDATIONS}

Te current survey covered a very limited area, with little of either preistoric or historic archaeological significance noted. No further action is recommended for LF4-1 (41 BX 473), the one prehistoric site found in Extension $1 F-4$. Little evidence of the two historic wells or accompanying structures was noted, and no further action is recommended for them. Since it is not known what sites may have been buried by stream sediments, it is recommended that the proper authorities be contacted if archaeological materials are uncovered during the future sewer pipeline work.

\section{REFERENCES CITED}

Barnes, V. E.

1974 Geologic Atlas of Texas, San Antonio Sheet. Bureau of Economic Geology, The University of Texas at Austin.

Fox, A. A.

1977 An Archaeological Assessment of the San Antonio 201 Wastewater Treatment Project Center Gor Archaealagical Research, The university of Texas at San Antonio, Archaeological Survey Report 41 . 